resigned to serve as civilian educational specialist at a U.S. Army university study centre in Europe.

Dr. Snell, a native of Binghamton, N.Y., has been active as teacher, research worker, author and leader in chemistry. She received the degree of bachelor of seience from Syracuse University in 1919, and for the next two years taught mathematics in a highschool. Her career in chemistry began after her marriage to Dr. Foster D. Snell in 1921. She took undergraduate courses at Barnard College, and pursued graduate studies at Columbia University, from which she received the M.A. degree in 1925 and the Ph.D. in 1930 . Dr. Snell became research assistant in the pediatric department of the Fifth Avenue Hospital, and then spent a short period in the pathology department of the College of Physicians and Surgeons, eventually joining the organization headed by her husband. Dr. Snell was secretary of the New York Section of the American Chemical Society during 1937-44, and is chairman of the Women's Service Committee of the American Chemical Society. She is the author, with Foster D. Snell, of "Colorimetric Methods of Analysis", in two volumes ; "Chemicals of Commerce" and "Chemistry Made Easy", in four volumes.

\section{Men of Science in the Modern State}

IN his speech at the closing plenary session of the Commonwealth and Empire Conference on Radio for Civil Aviation on August 20, Lord Winster, Minister of Civil Aviation, said that among several myths which have been destroyed during the War has been that of the superiority of German men of science and of the degree of co-ordination which had been arrived at in Germany between science and industrial and war production. The course of the War showed not only that the United Nations have men of science second to none, but also that we have been far more successful in marrying their knowledge and their labours into the national war effort. Furthermore, it is now acknowledged that in future provision must be made in Britain for the training in its colleges and universities of far more scientific and technical workers than in the past, and that the pursuit of a scientific career must be made much more attractive in such matters as status and salary. These facts, Lord Winster said, are now recognized "and recognition will, I believe, be translated into action".

Lord Winster continued in a vein which will recall many an article in these columns. We have seen, he said, in the field of research what teamwork backed by unlimited funds can do. We have entered into a field in which the man of science will bring us knowledge which not merely enriches and facilitates the progress of the world but also determines the lines which progress shall take. If this is so we must alter our outlook upon the man of seience ; no longer can he be regarded as an interesting but unpractical individual. Even in the War of 1914-18 he did not achieve any very tangible reeognition; in this War, thanks largely to Mr. Churchill, he has been eoming into his own, and from now on he will be part of the warp and woof of the national life. In the future, the scientific worker by his discoveries will be determining the course the world will take. For this reason he must be brought out of the 'backroom' and brought in at the very highest level, not only for consultation about national affairs but also as regards the actual direction of those affairs.

\section{Research in Animal Breeding and Genetics in Great Britain}

As part of the survey which the Agricultural Research Council, in conjunction with the Agricultural Improvement Councils for England and Wales and Scotland, has been making of fields of research in which expansion is needed, special attention has been given to animal breeding and geneties as a subject of outstanding importance. After considering advice on developments in this field given by a special survey group, for which the American Government generously made available the services of Dr. R. T. Clark of Montana, and after consultation with the departments of agriculture, the Agricultural Research Council has appointed to its scientific staff Prof. R. G. White, professor of agriculture in the University College of North Wales, Bangor, and Dr. C. H. Waddington, of the Department of Zoology, University of Cambridge. Their first task will be to prepare a scheme for the creation of a national organization for research in animal breoding and genetics, covering the needs of Great Britain. Prof. White will be the director and Dr. Waddington will be chief geneticist.

It will be necessary for Prof. White and Dr. Waddington to investigate the systems adopted in other countries for the development of research in this field, so that a complete scheme cannot be ready for some time, though certain investigations of a statistical and fundamental character can be started in the near future. It cannot, of course, be indicated at present what centre or centres will be chosen for the development of research. The Council is, however, anxious that in any new developments full advantage should be taken of the experience of the Institute of Animal Genetics at the University of Edinburgh, which for so long has contributed to knowledge of these subjects and has been the centre of postgraduate training for workers from many countries. Similarly, it is the Council's intention, by close co-operation with practical breeders and the representatives of the agricultural industry throughout Great Britain, as well as with Milk Marketing Boards and other interested organizations, that arrangements shall be made whereby records are kept in such a form as to give the greatest measure of assistance to research workers in the new organization, and to be of real value in guiding the improvement of livestock. Research on such slow-breeding animals as farm stock must necessarily be lengthy, and results which can be applied with confidence in breeding practice cannot, therefore, be expected to emerge quickly.

\section{International Co-operation in Social and Economic Fields}

A PAMPhLET, "The New I.L.O", issued by the British Association for Labour Legislation, with an introduction by Barbara Ward, considers the position of the International Labour Organisation in relation to the Economic and Social Council of the Dumbarton Oaks plan, with the object of stimulating discussion on the planning of intermational co-operation in social and economic matters. Reviewing the past experience of the International Labour Organisation, the pamphlet is criticel of the tripartite structure and questions the value of representation of employers except on the managerial or technical basis. A government should be the representative of the community as a whole, but governments should admit the workers also to the diseussion of economic as well as of social problems, primarily to provide tech- 